\title{
Virus culture studies in non-gonococcal urethritis
}

\author{
R. S. MORTON, E. H. GILlESPIE, AND M. A. WILSON \\ From the Special Traatment Clinic, Sheffield, and the \\ Public Health Laboratory, Sheffield
}

SYNOPSIS Specimens of urethal discharge and scrapings of the urethra from 45 men with non $=$ gonococcal urethritis have been studied for virus content. Human amnion and monkey kidney cel? cultures were inoculated. Various temperatures of incubation were used. Specimens were also inoculated into the yolk sac of seven-day fertile eggs.

No cytopathic changes were detected in any specimen examined after direct incubation or after $\vec{\Delta}$ passage. No elementary bodies were seen in stained sections of yolk sacs. Haemagglutination and음 haemadsorption tests were negative. Paired sera from 21 cases were available for antibody titre ${ }_{3}^{-}$ study. Estimations of urethral temperature and $p \mathrm{H}$ were made.

The cause of non-gonococcal urethritis remains to be discovered.

The commonest identifiable cause of urethritis in males is gonorrhoea. Next follow the trichomonal variety and the descending urethritis which may accompany bacterial cystitis. Chemical irritants and urethral stricture are rarer identifiable causes of non-gonococcal urethritis. There remains a large and steadily increasing number of cases of urethritis with no known cause. Since the Minister of Health first called for a return of the annual number of cases of non-gonococcal urethritis seen in venereal disease clinics in England and Wales the total has grown from 10,794 in 1951 to 24,472 in 1961 (Ministry of Health report (1962) for 1961).

Efforts to incriminate pleuro-pneumonia-like organisms as causative in non-gonococcal urethritis have not so far been successful (Collier. 1957; Csonka and Furness, 1960). Lindner (1910) was the first to describe inclusion bodies in urethral material from infected men and similar reports have followed (Thygeson and Mengert, 1936; Thygeson and Stone, 1942; Harkness, 1950; Siboulet, 1955). Not all workers are convinced, for example, Willcox (1954).

The inclusions described resemble those found in large virus infections, e.g., in the lymphogranuloma venereum group. In particular they resemble those found in inclusion blennorrhoea. Cervical scrapings from the mothers of babies with inclusion conjunctivitis have shown similar inclusions. Fritsch, Hofstätter, and Lindner (1910) claimed success in producing inclusion conjunctivitis in baboons with material from the urethra, cervix, and conjunctival sac, all of which showed similar inclusion bodies.

Received for publication 9 September 1963.
From the cervix of women, Jones, Collier, and Smith (1959) isolated viruses in the yolk sac of fertile eggs. Siboulet and Galistin (1962) claim to have shown evidence of the presence of virus ing chick embryo yolk sacs after inoculation of urethra屃 material from three cases of urethritis with Reiter's arthritis. Recently Jones (1964) has grown the virus? of inclusion blennorrhoea from urethral material of a father whose child had inclusion conjunctivitis. The wife had inclusions in cervical cells.

The attempts of others, particularly of Willcoxo (1954) and Ford (1956 and 1958), and Whittington' (1962) to grow viruses in chick embryos and a variety of tissue cell cultures have failed.

Complement-fixation tests with lymphogranuloma psittacosis-trachoma antigen have proved negative? in cases of non-gonococcal urethritis (Willcox, 1954) Such tests with inclusion blennorrhoea antigere. remain to be fully worked out (Jones, 1964). N

There is some support in the clinical field for a viral aetiolugy in non-gonococcal urethritis. A firs 0 attack almost always follows sexual exposure. Such a history is not so common in cases of recurrence? The recurrence rate was estimated by Morton and Read (1957) as $11.6 \%$ in 428 cases over a five-yearo period. They noted that the 'better' forms of treat? ment were more likely to be followed by relapse or뭉 recurrence, a phenomenon noted by Weston Hurst (personal communication) as common in experi@ mental viral infections in animals. It was also note $\mathbb{Q}$ by Morton and Read that empirical treatment of the regular consort with the antibiotic to which thes male partner responded made no difference to the 
recurrence/relapse rate of non-gonococcal urethritis. This has also been noted by Rosedale (1959).

Treatment of some virus diseases seems to be largely symptomatic, the virus continuing to live in symbiosis with the host. Erskine (1958) has noted the need for two spaced courses of treatment in lymphogranuloma. Weston Hurst (personal communication) has also noted how readily viruses can be found in the organs of 'cured' animals.

In some virus infections recurrence is apparently preceded by biochemical changes. Older venereologists recognized the appearance or recurrence of herpes zoster in patients receiving arsenicals and the recurrence of herpes labialis with fever is well known. There is a general impression that non-gonococcal urethritis may reappear after a high intake of alcohol. For all these reasons we have pursued a steady search for viruses in non-gonococcal urethritis cases. Although, like others, our results to date are negative we feel that they are of value in clearing the ground for future work by ourselves and others.

\section{CLINICAL MATERIAL}

Forty-five men suffering from non-gonococcal urethritis were studied. The average age was 31.3 years with extremes of 18 and 48 years. Seventeen patients were coloured. Twenty-one were married, or married and separated, while 24 were single or widowed. Thirteen were believed to have acquired the infection maritally and 32 extramaritally. The patients chosen were therefore typical of those suffering from non-gonococcal urethritis.

\section{ROUTINE FOR COLLECTION OF SPECIMENS}

To exclude gonorrhoea and trichomonal infection, Gram-stained and wet specimens of urethral discharge were examined microscopically. Cultures for both organisms were also set up.

In the belief that our chances of finding a virus would be enhanced by cutting out transportation of specimens all patients were taken to and examined in the laboratory. Under such conditions culture material could be inoculated with minimal delay.

Two specimens were taken from each infected urethra, one of the discharge itself and one a scraping of the urethral epithelium after micturition. Before the taking of each of these specimens the meatus was cleaned with dry cotton wool only. It was found that cleaning with saline or spirit sweeps surface bacteria into the urethra and produces a high percentage of contaminated Gram-stained specimens. Urethral scrapings were taken with a firm platinum loop 2 in. in length in the earlier cases. Later a fine curette was used and found to be much more readily productive of inoculum. Specimens of urethral discharge and epithelial scrapings were placed in each of two bijou bottles, i.e., four bottles in all. Each bottle contained $3 \mathrm{ml}$. of medium A or medium B with glass beads. The composition of these media was as follows:
MEDIUM A

$0.5 \%$ lactalbumin in Hanks' solution ....100 ml.

Calf serum ...................... $3 \mathrm{ml}$.

$4.4 \%$ sodium bicarbonate $\ldots \ldots \ldots \ldots \ldots .4 \mathrm{ml}$.

Plus antibiotics when used Penicillin ...200 units $/ \mathrm{ml}$.

or Streptomycin.. $200 \mu \mathrm{g} / \mathrm{ml}$.

MEDIUM B

$0.5 \%$ lactalbumin in Hanks' solution . ...100 ml. $7.0 \%$ bovine albumin (Armour

fraction $\mathrm{V})$.....................

$4.4 \%$ sodium bicarbonate .............

With antibiotics as above

plus Kanamycin .............. $100 \mu \mathrm{g} / \mathrm{ml}$.

After the addition of the urethral material the bijou bottles were shaken vigorously 10 times by hand.

\section{TISSUE CULTURE INOCULATION AND INCUBATION}

The maintenance medium was removed from 16 tissue culture tubes of either monkey kidney or human amnion cells, depending on which was available at the requisite time. From each bijou bottle $0.5 \mathrm{ml}$. was inoculated into four tissue culture tubes, two of each four being incubated at $37^{\circ} \mathrm{C}$. and the other two at $30^{\circ} \mathrm{C}$. After the first 13 patients had been studied a $33^{\circ} \mathrm{C}$. incubator became available and this temperature was used instead of $30^{\circ} \mathrm{C}$. The tissue culture tubes were examined the day after inoculation for possible toxicity or contamination and thereafter every two days for up to 28 days when cytopathic changes were sought. During the 28 days, blind passages, usually two to four in number, were made when the cells degenerated. As many cells as possible were moved from the side of the tube by shaking and/or scraping and the mixture of fluid and cells was shaken vigorously. Of this mixture $0.1 \mathrm{ml}$. was added to fresh tissue culture tubes containing $0.5 \mathrm{ml}$. of the appropriate medium.

Haemagglutination and haemadsorption tests were also carried out as follows:

HAEMAGglutination tests The tissue culture fluid was removed from each tube. To $0 \cdot 25 \mathrm{ml}$. tissue culture fluid in a cup of a plastic plate was added $0.25 \mathrm{ml}$. of $0.5 \%$ fowl cell suspension in phosphate-buffered saline. This was left at $+4^{\circ} \mathrm{C}$. for one hour and then examined macroscopically for haemagglutination.

HAEMADSORPTION TESTS After removal of the tissue culture fluid, the cell sheet was washed three times with phosphate buffered saline; $0.3 \mathrm{ml}$. of $0.5 \%$ fowl cells in phosphate buffered saline was then added, the tube sloped and left stationary at $+4^{\circ} \mathrm{C}$. for 10 minutes. The tube was then gently shaken and left for another 10 minutes at $+4^{\circ} \mathrm{C}$. After this time the fowl cells were removed and the cell sheet washed once gently with phosphate-buffered saline. With a low-powered objective the cell sheet was examined for haemadsorption.

As regards the haemagglutination testing this is based on the observation that living cells are impermeable to antibody and that intracellular viruses are therefore protected from the action of antibody. Intracellular 
virus material, particularly influenza virus, can, however, be detected by the observed agglutination of red cells on cell surfaces. The phenomenon of union of red cells with intracellular virus is dependent on the presence of mucoprotein receptors on the cell surface acting as a catalyst.

The term haemadsorption refers to the aggregation of red cells on infected tissue culture cells and has been observed in a few varieties of upper respiratory viruses.

At the time of investigating the thirty-second patient, streptomycin, $200 \mu \mathrm{g} . / \mathrm{ml}$., was substituted for penicillin in the medium. Streptomycin alone is relatively ineffective treatment for non-gonococcal urethritis and while penicillin in high dosage has some curative effect in lymphogranuloma venereum and trachoma, it has little effect in non-gonococcal urethritis. Later in the series Kanamycin was also used.

The use of medium A was discontinued after the thirtyfirst patient.

\section{EGG INOCULATION}

As from the thirty-third patient, specimens were, in addition, inoculated into the yolk sac of fertile seven-day eggs, using the following technique.

The eggs were candled. The air sac and a spot between the vessels was marked. After painting the shell with iodine, holes were punched out with a sterile 6 in. nail (or similar pointed instrument) down to, but not through the shell membrane, one hole in the centre of the air sac and the other at the spot between the vessels. With a Mantoux syringe 0.2 to $0.3 \mathrm{ml}$. of medium $B$ with inoculum was inoculated into five eggs. The needle was inserted for about $\frac{1}{2}$ in. into the hole between the vessels in order to introduce material into the yolk sac. Both shell holes were then sealed with wax. Four eggs were then similarly treated with medium B only. The eggs were incubated at $36^{\circ} \mathrm{C}$. and candled daily for nine to 10 days. Any embryos showing only sluggish movement or none at all were chilled and the yolk sac was harvested. All those which died were found to be contaminated with bacteria: more usually Streptococcus faecalis but occasionally coliform bacilli were found. The addition of Kanamycin, $10 \mu \mathrm{g} . / \mathrm{ml}$., went some way to control this process.

After harvesting, all yolk sacs were washed with Dulbecco A. Sections were cut and stained overnight with a mixture of equal parts Gurr's and Lilly's Giemsa each diluted approximately 1 in 50 in 6.8 buffer and differentiated with 1 in 5,000 to 1 in 10,000 glacial acetic acid.

\section{ADDITIONAL STUDIES}

All patients had routine testing for syphilis using Wassermann, Kahn, and Reiter protein complementfixation tests. Specimens of blood were also taken initially and in 21 cases four to six weeks later, and were preserved at $-20^{\circ} \mathrm{C}$. for estimation of antibody content against any virus which might be isolated by ourselves or others.

Temperature studies of the male urethra were run concurrently. A highly sensitive potentiometer-type thermometer was used. The thermocouple was inserted 3 in. inside the urethra of uninfected patients. Readings: ranging from $32 \cdot 8^{\circ} \mathrm{C}$. to $37 \cdot 7^{\circ} \mathrm{C}$. with an average of $33 \cdot 6^{\circ} \mathrm{C}$. were found.

One hundred urine samples were tested for $p H$ level by B.D.H. wide-range indicator papers. Forty samples from uninfected males gave readings ranging from 4 to 8 with an average of $5 \cdot 4$. Pus-contaminated urine from 32 malese with acute gonorrhoea gave readings from 4 to 90 with an average of $6 \cdot 1$. Similar specimens from mensuffering from non-gonococcal urethritis gave readings. ranging from 4 to 8.5 with an average of 6.5 .

\section{RESULTS}

All searches to locate cytopathic changes in celliv lines and eggs were fruitless. Haemagglutination and haemadsorption tests were negative.

\section{DISCUSSION}

Viruses may have been present but were not found. Perhaps the urethritis is a manifestation of infection elsewhere in the way that the pustules of herpese zoster are a manifestation of infection of posterior ${ }^{+}$ nerve roots. We should perhaps look elsewhere than the urethra for the presumed virus, e.g., in the faecess or the cerebrospinal fluid. Perhaps incubation in roller cultures with particular attention to temperature, $p \mathrm{H}$, and composition of the medium may@ prove helpful.

Our thanks are due to the Sheffield Regional HospitaP Board for a grant in support of this work. We are also indebted to Drs. E. Weston Hurst and J. M. Mungavin or the Pharmaceutical Division of I.C.I., Alderley Park Macclesfield, Cheshire, for their practical assistance? supply of incubators and encourayement. The day to days loyal support of our nursing and technical staffs is greatly appreciated.

\section{REFERENCES}

Collier, L. H. (1957). Nature (Lond.), 180, 757.

Csonka, G. W., and Furness, G. (1960). Brit. J. vener. Dis., 36, 181. OC Erskine, D. (1958). Ibid., 34, 163.

Ford, D. K. (1956). Ibid., 32, 184.

- (1958), Ibid., 34, 53. Graefes Arch. Ophthal. 76, 547 (cited by Harkness 1950).

Harkness, A. H. (1950). Non-gonococcal Urethritis. Livingstone Edinburgh.

Hurst, E. Weston (1962). Personal communication.

Jones, B. R. (1964). Brit. J. vener. Dis., 40, in press.

Collier, L. H., and Smith, C. H. (1959). Lancet, 1, 902.

Lindner, K. (1910). Wien. klin. Wschr., 23, 283.

Ministry of Health (1962). Report for 1961. Pt. 2, Appendix C, Cmnd. 1856. p. 58.

Morton, R. S. and Read, L. (1957). Brit. J. vener. Dis., 33, 223.

Rosedale, N. (1959). Ibid., 35, 245.

Siboulet, A. (1955). Ibid., 31, 235.

, and Galistin, P. (1962). Ibid., 38, 209.

Thygeson, P., and Mengert, W. F. (1936). Arch. Ophthal., 15, 377. $\longrightarrow$, and Stone, W. (1942). Ibid., 27, 91.

Whittington, M. J. (1962). Brit. J. vener. Dis. 38, 200

Willcox, R. R. (1954). Brit. med. J., 1, 13.

\section{(1)}

